\title{
The Impact of Trade Liberalization on Water Use: A Computable General Equilibrium Analysis
}

\author{
Maria Berrittella \\ University of Palermo \\ Katrin Rehdanz \\ University of Kiel \\ Richard S.J. Tol \\ Economic and Social Research Institute \\ Jian Zhang \\ University of Hawaii
}

\begin{abstract}
We used the GTAP-W model - GTAP version 5 with water resources added - to estimate the impact of hypothetical Doha-like liberalization of agricultural trade on water use. Three conclusions emerge. First, the change in regional water use is less than 10 per cent relative to the baseline in 2010, even if agricultural tariffs are reduced by 75 per cent. Second, patterns are non-linear. Water use may go up for partial liberalization, and down for more complete liberalization. This is because different crops respond differently to tariff reductions, but also because trade and

\footnotetext{
* Maria Berrittella: Centro Interdipartimentale di Ricerche sulla Programmazione Informatica dell'Economia e delle Tecnologie (CIRPIET), University of Palermo, Palermo, Italy,

Corresponding author: Katrin Rehdanz: Christian-Albrechts University of Kiel, Deparment of Economics, Olshausenstrasse 40, 24118 Kiel, Germany, Tel: +40 431 8814-407, Fax: +40 43185853 , E-mail: katrin.rehdanz@ifw-kiel.de, Kiel Institute for the World Economy, Kiel, Germany, Richard S.J. Tol: Economic and Social Research Institute, Dublin, Ireland, Institute for Environmental Studies, Vrije Universiteit, Amsterdam, The Netherlands, Engineering and Public Policy, Carnegie Mellon University, Pittsburgh, PA, USA, Jian Zhang: Economic Research Organization, University of Hawaii, Honolulu, USA 
competition matter too. Third, trade liberalization tends to reduce water use in water scarce regions, and increase water use in water abundant regions, even though water markets do not exist in most countries.

- JEL Classification: D58, F13, Q17, Q25

- Key words: computable general equilibrium, trade liberalization, water policy, water scarcity

\section{Introduction}

Trade liberalization policies can be effective in stimulating economic growth and reducing the poverty gap by expanding market access opportunities. In particular, agricultural trade liberalization is supposed to be beneficial, if developing countries' comparative advantages are located in agriculture. Therefore, the protectionist agricultural policies of OECD countries are often criticized. The Doha Development Agenda, launched in 2001, is meant to improve the situation, but is subject to seemingly interminable delays.

There is an extensive literature on the costs and benefits of trade liberalization in general and agricultural trade in particular using different approaches, data and trade liberalization scenarios. The most recent publications are related to the Doha Round. Depending on the scenario chosen, most studies find a positive economic effect of agricultural trade liberalization for developing countries (for some recent studies see e.g. Anderson et al., 2006, or Francois et al., 2005); Bureau et al. (2006) are less favorable.

However, trade liberalization is unambiguously welfare-improving only if property rights are well-defined (Chichilnisky, 1994). This is rarely the case for environmental resources, particularly in developing countries. In this paper, we focus on the impacts of agricultural trade liberalization on water use - where markets and property rights exist in only a few countries. Changes in tariffs or subsidies for agricultural goods involve regional as well as global adjustments in the production of the goods in question but have effects on other markets, such as factor input markets, as well. Water is one production factor in agriculture.

In 2000 about 70 per cent of all water in production is used for agriculture. Although water is already scarce in many countries, improvements to economize on the con- sumption are proceeding slowly. For some developing countries the average irrigation efficiency is far below what is technically possible. The current 
level and structure of water charges mostly do not encourage farmers to use water more efficiently. In many regions, water use is even subsidized. This is partly because of desired food self-sufficiency (Ahmad, 2000). However, food demand could be met by importing more water-intensive food from water abundant countries, and producing and exporting commodities that are less water-intensive. The water embodied in commodities is also known as virtual water (Allan, 1992, 1993). So far, few studies provide estimates of global virtual water trade (see e.g. Chapagain and Hoekstra, 2004). Trade liberalization in agriculture would affect virtual water trade and might enhance or alleviate problems related to water use and water availability. To our knowledge, this has not been investigated in a multiregion, multi-sector general equilibrium model. The analysis of the present study is based on scenarios related to the Doha Agenda.

Most of the current analyses on agricultural trade liberalization ignore the impact on water use and problems related to water availability. Some authors have looked at the potential impact on sustainable development in developing countries including water as an environmental service. George and Kirkpatrick (2004) state in their qualitative analysis that further trade liberalization would lead to improved overall availability of water through increased efficiency in all developing countries. ${ }^{1}$ Their study does not distinguish between different developing countries nor is a quantitative assessment provided. Other studies related to water issues investigate the implications of the GATS negotiations on service trade liberalization on water management and the ability of governments to regulate water services (see e.g. Watson, 2004 or Kirkpatrick and Parker, 2005). All these analyses are qualitative assessments not based on economic models. Economic models of water use, discussed in the following section, have yet to investigate the role of trade liberalization on water use or water availability.

Our analysis is based on countries' total renewable water resources and differences in water productivity. Growing wheat in North Africa requires more water than growing it in Germany. Also, different crop types have different crop water requirements; and regions grow different crop varieties. For example, the production of a ton of rice is more water intensive than the production of a ton of wheat. In this paper, we do not look at a reallocation of water, but we do look at a reallocation of water-intensive products. National and international markets of agricultural products would be affected. A complete understanding of a water policy is

${ }^{1}$ They mention that regulatory and subsidy frameworks are critical. 
therefore impossible without understanding the international markets for food and other agricultural products, such as textiles. We use the computable general equilibrium (CGE) model GTAP-W which allows for a rich set of economic feedbacks and for a complete assessment of the welfare implications.

The remainder of the paper is organized as follows: the next section II briefly reviews the literature on economic models of water use. Section III presents the model used and the data on water resources and water use. The basic model is available free of charge and the corresponding data can be purchased from the Global Trade and Analysis Project (Dimaranan and McDougall, 2002). The water data can be downloaded at: http://www.fnu.zmaw.de/GTAP-EF-W.5680.0.html. Section IV lays down the four simulation scenarios with no constraints on water availability. Section V discusses the results and section VI concludes.

\section{Economic Models of Water Use}

Economic models of water use have generally been applied to look at the direct effects of water policies, such as water pricing or quantity regulations, on the allocation of water resources. Indirect effects through economic change, initiated by e.g. trade liberalization, have not been the focus.

In order to obtain insights from alternative water policy scenarios on the allocation of water resources, partial and general equilibrium models have been used. While partial equilibrium analysis focus on the sector affected by a policy measure assuming that the rest of the economy is not affected, general equilibrium models consider other sectors or regions as well to determine the economy-wide effect; partial equilibrium models tend to have more detail. Most of the studies using either of the two approaches analyze pricing of irrigation water only (for an overview of this literature see Johannson et al., 2002). Rosegrant et al. (2002) use the IMPACT-Water model to estimate demand and supply of food and water to 2025. Fraiture et al. (2004) extend this to include virtual water trade, using cereals as an indicator. Their results suggest that the role of virtual water trade is modest. While the IMPACT-Water model covers a wide range of agricultural products and regions, other sectors are excluded; it is a partial equilibrium model.

Studies of water use using general equilibrium approaches are generally based on data for a single country or region assuming no effects for the rest of the world of the implemented policy. Therefore, none of these studies is able to look at the global impact of multilateral trade liberalization. Decaluwe et al. (1999) analyze 
the effect of water pricing policies on demand and supply of water in Morocco. Diao and Roe (2003) use an intertemporal CGE model for Morocco focusing on water and trade policies. Seung et al. (2000) use a dynamic CGE model to estimate the welfare gains of reallocating water from agriculture to recreational use for the Stillwater National Wildlife Refuge in Nevada. Letsoalo et al. (2007) study the effects of water charges on water use, economic growth, and the real income of rich and poor households in South Africa. For the Arkansas River Basin, Goodman (2000) shows that temporary water transfers are less costly than building new dams. Strzepek et al. (2006) estimate the economic benefits of the High Aswan Dam. Gómez et al. (2004) analyze the welfare gains by improved allocation of water rights for the Balearic Islands. Feng et al. (2007) is an interesting study for China using a two-region recursive dynamic general equilibrium approach based on the GREEN model (Lee et al., 1994) to assess the economic implications of the increased capacity of water supply through the Chinese South-to-North Water Transfer (SNWT) project. All of these CGE studies have a limited geographical scope.

Berrittella et al. (2007) are an exception. They use a global CGE model including water resources (GTAP-W) to analyze the economic impact of restricted water supply for water-short regions. They contrast a market solution, where water owners can capitalize their water rent, to a non-market solution, where supply restrictions imply productivity losses. They show that water supply constraints could actually improve allocative efficiency, as agricultural markets are heavily distorted. The welfare gain from curbing inefficient production may more than offset the welfare losses due to the resource constraint. Berrittella et al. (2008) use the same model to investigate the economic implications of water pricing policies. They find that water taxes reduce water use, and lead to shifts in production, consumption and international trade patterns. Countries that do not levy water taxes are nonetheless affected by other countries' taxes. Like Feng et al. (2007), Berrittella et al. (2006) analyze the economic effects of the Chinese SNWT project. Their analysis, based on GTAP-W, offers less regional detail but focuses in particular on the international implications of the project. This paper extends the previous papers of Berrittella et al. by looking at the impact of trade liberalization on water use. The studies described above focus on the direct link between changes in water policies and the allocation of water resources. Unlike those analyses, the present study is concerned with the indirect effect on water use arising due to trade liberalization. 


\section{Modeling Framework and Data}

As in most CGE models, the GTAP-W model makes use of the Walrasian competitive market equilibrium paradigm to simulate adjustment processes. ${ }^{2}$ Industries are modeled through a representative firm, which maximizes profits in perfectly competitive markets. The production functions are specified via a series of nested CES functions (Figure A1 in Annex I). Domestic and foreign inputs are imperfect substitutes, according to the so-called "Armington assumption", which accounts for product heterogeneity.

A representative consumer in each region receives income, defined as the service value of national primary factors (natural resources, land, labour and capital). Capital and labour are perfectly mobile domestically, but immobile internationally. Land and natural resources are industry-specific and imperfectly mobile. The national income is allocated between aggregate private household consumption, public consumption and savings (see Hertel, 1997, for more detail) and governed by a Cobb-Douglas utility function. Private consumption is split in a series of alternative composite Armington aggregates. The functional specification used at this level is the Constant Difference in Elasticities (CDE) form: a non-homothetic function, which is used to account for possible differences in income elasticities for the various consumption goods. A money metric measure of economic welfare, the equivalent variation, can be computed from the model output.

In our modeling framework, water is combined with the value-added-energy nest and the intermediate inputs as displayed in Figure A1 (Annex I) through a Leontief formulation. As in the original GTAP model, there is no substitutability between intermediate inputs and value-added for the production function of tradeable goods and services. Therefore, a price-induced drop in water demand does not imply an increase in any other input. That is, water is a factor of production, but not a substitutable one. However, we do assume that water use decreases with price increases, and this relationship is less than linear. The model therefore mimics water conservation, although it ignores the resources required to conserve water. In a future version of the model, we hope to improve on this specification.

\footnotetext{
${ }^{2}$ See table A1 (Annex I) for the regional, sectoral and factor aggregations used in GTAP-W. The model is a refinement of the GTAP model in the version modified by Burniaux and Truong (2002). The GTAP model is a standard CGE static model distributed with the GTAP database of the world economy (www.gtap.org). For detailed information see Hertel (1997) and the technical references and papers available on the GTAP website.
} 
In the benchmark equilibrium, water supply is supposed to be unconstrained, so that water demand is lower than water supply, and the price for water is zero. The reason for implementing water in this way is the lack of adequate data on the value of water in agriculture and other water-using sectors. (The implementation is discussed in more detail below.) Water is supplied to the agricultural industry, which includes primary crop production and livestock, and to the water distribution services sector, which delivers water to the rest of the economic sectors. Note that distributed water can have a price, even if primary water resources are in excess supply. Furthermore, water is mobile between the different agricultural sectors. However, water is immobile between agriculture and the water distribution services sector, because the water treatment and distribution functions are very different between agricultural and other uses.

The key parameter for the determination of regional water use is the water intensity coefficient. This is defined as the amount of water necessary for a sector to produce one unit of a given commodity. This refers to water directly used in the production process, not to the water indirectly needed to produce other input factors. To estimate water intensity coefficients, we first calculated total water use by commodity and country for the year 1997. For the agricultural sector the FAOSTAT database (FAO, 2005) provided information on production of primary crops and livestock. This includes detailed information on different crop types and animal categories. Information on water requirements for crop growth and animal feeding was taken from Chapagain and Hoekstra (2004). ${ }^{3}$ The water requirement includes both the use of blue water (ground and surface water) as well as green water (moisture stored in soil strata). For crops it is defined as the sum of water needed for evapotranspiration, from planting to harvest, and depends on crop type and region. This procedure assumes that water is not short and no water is lost by irrigation inefficiencies. For animals, the virtual water content is mainly the sum of water needed for feeding and drinking. The water intensity parameter for the water distribution sector is based on the country's industrial and domestic water use data provided by AQUASTAT (FAO, 2003). This information is based on data for 2000. By making use of these data we assume that domestic and industrial water uses in 2000 are the same as in 1997. While this is clearly incorrect, the degree of error introduced due to this assumption is likely to be quite small.

The data we use are imperfect. Water use by crop is uncertain, variable, and

${ }^{3}$ This information is provided as an average over the period from 1997 to 2001 and the CGE model is calibrated for 1997. 
estimated with a rough methodology; Chapagain and Hoekstra (2004) do not distinguish between rainfed and irrigated agriculture. The AQUASTAT database has similar problems for water use, as well as for water resources. The FAOSTAT database on crop production has a mix of high and low quality data. Nonetheless, there are no databases with equal coverage, both in countries and in crop detail, and higher quality.

If water supply falls short of demand, consumers would be rationed, and would be willing to pay a price to access water. If water resources are privately or collectively owned, the owners receive a rent, which adds to income. The price for water is set by the market at the level that makes water demand compatible with supply. In this setting, water supply would be assumed to be completely inelastic (vertical). If supply exceeds demand, additional economic rents are not generated and the initial price remains unchanged.

Finally, we make the link between output levels and water demand sensitive to water prices. In other words, we assume that more expensive water brings about rationalization in usage. The opposite happens if more water would be available. The actual capability of reducing the relative intensity of water demand is industryspecific, and captured by a sector-and-region specific parameter (Table A2 in Annex I), or rather the production cost elasticity to water demand. Note that the parameters are little more than informed guesses, derived from Rosegrant et al. (2002). Details are given in Annex II.

The mechanism through which the demand for water reacts to trade liberalization is the following: if the import tax on water intensive agricultural products in one region decreases, the demand for water in that region decreases as well and increases in other regions. As the import of water intensive products from abroad has become less expensive the region substitutes imports for domestic inputs for production. On the contrary, if the import tax for products not using water in their production decreases, the demand for water in water intensive sectors will likely increase. In our simulation scenarios, discussed in the next section, water availability is unconstrained. Trade liberalization leads to adjustments in the production and the model calculates the corresponding change in water demand.

\section{Design of Model Experiments}

As the Doha negotiations are still ongoing (albeit at a very slow pace), the modalities of the possible agreement are uncertain. It is clear that the parties 
involved have very different interests. Agricultural exporters aim for open foreign markets and reductions in distorting subsidies elsewhere. Industrial exporters in emerging economies want to remain protected. Countries with comparative advantages in services wish the GATS negotiations would be successful in reducing national regulatory in services. Therefore, any analysis investigating scenarios of trade liberalization have to take all three aspects into account. However, as our study focuses on trade liberalization in agriculture, we account for liberalization in non-agricultural sectors, but vary the levels of liberalization for the agricultural sectors only. The cut in tariffs for products in the non-agricultural sectors is 25 per cent.

In scenario 1, a 25 per cent tariff reduction is chosen for all agricultural sectors. In addition, we assume zero export subsidies and a 50 per cent reduction in domestic farm support. Scenarios 2 and 3 are variants of scenario 1: tariffs are reduced by 50 per cent and 75 per cent respectively. ${ }^{4}$ This last scenario is the most ambitious one. In scenario 4 developed and developing countries are treated differently. For industrialised countries the tariff reduction is set to 75 per cent while developing countries reduce tariffs by 50 per cent only.

According to the negotiations so far, export subsidies will be phased out over a few years. Tariff reductions will also not be implemented at once but phased in. To account for this procedure, we designed our above-described scenarios for the year 2010. As GTAP-W is calibrated to 1997 we had to derive a hypothetical dataset for 2010 before analysing the impact of trade liberalization. We divided the procedure in two steps. In the first step the hypothetical dataset for 2010 is generated. In the second step the scenarios are calculated as deviations from the new 2010 baseline. The first step entails forecasting values for some key economic variables including land and labour productivity, population, labour force and capital stock in order to identify a hypothetical general equilibrium state in the future. The data as well as the procedure applied is explained in detail in Appendix III. In our simulation from 1997 to 2010, labour force, population, productivity growth and initial capital stocks are all exogenous to the model. In the trade liberalization scenarios, we fixed the new levels of tariffs, export subsidies and domestic farm support as outlined above, allowing production to adjust.

Table 1 provides detailed information on the regional characteristics related to the availability and use of water for 1997 and 2010 for the baseline (no trade liber-

\footnotetext{
${ }^{4}$ A scenario with a complete removal of agricultural tariffs could not be solved, neither for 1997 nor for
} 2010. Some input factors are limiting the process of adjustment such that no new equilibrium can be found. 
Table 1. Regional Characteristics Related to Water Availability and Water Use for the Baseline (1997 and 2010)

\begin{tabular}{|c|c|c|c|c|c|c|c|c|c|c|}
\hline & \multicolumn{2}{|c|}{ Renewable water resources ${ }^{\mathrm{a}}$} & \multirow{2}{*}{$\begin{array}{c}\begin{array}{c}\text { Water intensity in } \\
\text { agriculture }^{\mathrm{c}}\end{array} \\
\mathrm{m}^{3} / \$\end{array}$} & \multirow{2}{*}{$\begin{array}{c}\text { Water intensity } \\
\text { other }^{\text {d }}\end{array}$} & \multicolumn{2}{|c|}{$\begin{array}{c}\text { Water use } \\
\left(10^{9} \mathrm{~m}^{3} \text { per year }\right)\end{array}$} & \multicolumn{2}{|c|}{$\begin{array}{l}\text { Water imports } \\
\qquad\left(10^{9} \mathrm{~m}^{3}\right)\end{array}$} & \multicolumn{2}{|c|}{$\begin{array}{l}\text { Water exports } \\
\qquad\left(10^{9} \mathrm{~m}^{3}\right)\end{array}$} \\
\hline & $10^{9} \mathrm{~m}^{3}$ per year & $\mathrm{m}^{3} /$ person $^{\mathrm{b}}$ & & & 1997 & 2010 & 1997 & 2010 & 1997 & 2010 \\
\hline USA & 3069 & 11120 & 2.9 & 3.7 & 479 & 761 & 57 & 73 & 125 & 218 \\
\hline CAN & 2902 & 96733 & 4.3 & 5.2 & 46 & 63 & 8 & 11 & 51 & 55 \\
\hline WEU & 2227 & 5740 & 2.6 & 3.5 & 227 & 313 & 256 & 290 & 96 & 136 \\
\hline JPK & 500 & 2907 & 1.4 & 1.6 & 107 & 138 & 82 & 92 & 0 & 1 \\
\hline ANZ & 819 & 37227 & 4.1 & 1.2 & 26 & 37 & 3 & 4 & 30 & 41 \\
\hline EEU & 494 & 4083 & 3.3 & 13.6 & 60 & 80 & 19 & 19 & 6 & 9 \\
\hline FSU & 4730 & 16254 & 9.1 & 28.0 & 284 & 350 & 27 & 32 & 61 & 51 \\
\hline MDE & 483 & 2128 & 4.9 & 6.8 & 206 & 220 & 35 & 45 & 19 & 14 \\
\hline CAM & 1183 & 9242 & 5.2 & 13.6 & 101 & 144 & 25 & 37 & 31 & 44 \\
\hline SAM & 12246 & 36886 & 3.9 & 5.9 & 164 & 196 & 35 & 44 & 68 & 83 \\
\hline SAS & 3685 & 2859 & 9.8 & 47.5 & 918 & 1428 & 21 & 35 & 25 & 31 \\
\hline SEA & 5266 & 8254 & 10.1 & 12.8 & 279 & 383 & 58 & 69 & 35 & 59 \\
\hline $\mathrm{CHI}$ & 2897 & 2274 & 3.6 & 38.5 & 630 & 1605 & 33 & 96 & 16 & 13 \\
\hline NAF & 107 & 793 & 8.5 & 39.5 & 95 & 121 & 27 & 41 & 4 & 3 \\
\hline SSA & 4175 & 6901 & 11.4 & 6.4 & 113 & 139 & 14 & 18 & 132 & 148 \\
\hline ROW & 2984 & 71048 & 4.7 & 2.7 & 75 & 84 & 6 & 7 & 8 & 7 \\
\hline
\end{tabular}

a2001 estimates taken from Aquastat.

bUN criterion for water resource scarcity degree: slightly scarce (1700-3000), middle scarce (1000-1700), severe scarcity (500-1000) and most severe scarcity $(<500)$.

${ }^{c}$ Average water intensity covering crop/plant growth and animal production measured in water use/ $\$$ output. Numbers differ considerably between countries and sectors. Note that water use includes the use of different kind of sources; rain, soil moisture and irrigation water. However, farmers pay for irrigation water only. ${ }^{\mathrm{d}}$ Note that in some countries only a low number of persons is connected to a distribution network. In others a number of self-supplied industries are not connected. However, both are included as users of the services the water distribution network provides. As a consequence, water use per $\$$ of output is overstated in the above table. 
alization). The most significant changes occur in China where the demand for water as well as the import of water-intensive products increase most markedly while export of water-intensive products decrease. Changes in water use in regions such as South-Asia and the USA are much less pronounced.

\section{Simulation Results}

Table 2 gives the baseline production in the water-intensive agricultural sectors. In the first three liberalization scenarios, countries like Canada, Australia and New Zealand, and the USA (scenario 3) would increase their production of rice to make up for the reduced production elsewhere. However, the baseline production of rice in these regions is very small, and although the increase is a large percentage, total production after trade liberalization is still small. More importantly, the production in Japan and South Korea decreases quite significantly and the more so the stricter the liberalization. On the contrary, developing countries in Asia (including South Asia, South-East Asia and China) would increase their rice production, and more so for further liberalization.

Wheat production in Canada, the USA and Eastern Europe increases with higher levels of trade liberalization while countries in Western Europe reduce their production. The former Soviet Union increases production but with a decreasing rate. For Australia and New Zealand, changes in production are negative in scenario 3.5 For many developing regions (including Africa) the effects are increasingly negative. Only China, the Middle East and South America increase their production throughout. For Central America and South-East Asia, there are opposite signs for different levels of liberalization as the general equilibrium effects dominate the initial impact of reduced tariffs.

For most developing regions, deeper liberalization negatively affects production of other cereals. Only countries in South America increase their production throughout. In Canada and Australia and New Zealand, the effect is increasingly positive. The opposite is true for Western Europe, the former Soviet Union and Japan and South Korea. Interestingly, for many regions, a modest liberalization affects production positively while a more ambitious liberalization has a negative effect. The opposite is true for the USA: scenario 1 has a negative effect while

\footnotetext{
${ }^{5}$ As previously discussed in the text, the significant negative changes in Japan and South Korea are of limited importance, since the production in the baseline is small. The same applies to changes in the production of cereals and other crops.
} 
Table 2. Changes in Production: Results for Scenarios 1 to 4 (Relative to the Baseline)

\begin{tabular}{|c|c|c|c|c|c|c|c|c|c|c|c|c|c|c|c|c|}
\hline & \multicolumn{4}{|c|}{ Rice $(\%)$} & \multicolumn{4}{|c|}{ Wheat $(\%)$} & \multicolumn{4}{|c|}{ Cereals and other crops (\%) } & \multicolumn{4}{|c|}{ Vegetables and fruits (\%) } \\
\hline & Scen. 1 & Scen. 2 & Scen. 3 & Scen. 4 & Scen. 1 & Sce & $\mathrm{Sc}$ & Scen. 4 & Scen & Sce & Sce & Scen. 4 & Scen. 1 & 2 & Sce & Scer \\
\hline USA & -12.54 & -8.94 & 1.39 & 1.15 & 0.07 & 0.99 & 1.87 & 1.31 & -0.22 & 0.80 & 1.63 & 0.96 & -1.27 & 2.55 & 7.90 & 3.59 \\
\hline CAN & 24.21 & 24.87 & 26.60 & 26.49 & 4.40 & 7.30 & 10.86 & 8.99 & 1.65 & 3.41 & 5.97 & 2.66 & 1.99 & 1.18 & 0.45 & 0.09 \\
\hline WEU & -1.75 & -9.41 & -17.49 & -17.57 & -1.47 & -1.57 & -1.80 & -2.09 & -2.02 & -2.34 & -2.64 & -2.78 & -2.37 & -3.36 & -4.52 & -4.70 \\
\hline JPK & -0.58 & -2.06 & -5.76 & -5.77 & -22.25 & -43.31 & -61.82 & -61.83 & -6.87 & -15.01 & -24.42 & -24.25 & -2.39 & -5.61 & -9.61 & -9.66 \\
\hline ANZ & 12.14 & 32.64 & 97.98 & 97.97 & 1.05 & 0.09 & -1.31 & -0.66 & 3.35 & 7.67 & 14.61 & 7.54 & 0.06 & -1.39 & -2.99 & -2.04 \\
\hline EEU & -0.71 & -0.92 & -1.12 & -1.11 & 1.35 & 1.73 & 2.37 & 1.64 & 0.10 & -0.34 & -0.73 & -0.88 & 0.39 & -0.17 & -0.76 & -0.77 \\
\hline FSU & -0.54 & -0.54 & -0.54 & -0.54 & 1.29 & 1.25 & 1.20 & 1.09 & 0.04 & -0.83 & -1.66 & -1.53 & -0.25 & -1.44 & -2.62 & -2.30 \\
\hline MDE & 0.23 & 0.21 & 0.19 & 0.21 & 2.16 & 2.34 & 2.58 & 2.34 & 1.80 & -0.99 & -3.85 & -0.56 & 1.74 & 1.56 & 1.38 & 1.60 \\
\hline CAM & 2.93 & 1.95 & 0.96 & 2.24 & -3.51 & -1.33 & 3.05 & 3.28 & -1.62 & -3.51 & -5.39 & -4.06 & 3.01 & 4.51 & 6.82 & 6.91 \\
\hline SAM & 0.77 & 0.94 & 1.18 & 0.90 & 1.33 & 1.27 & 1.32 & 1.22 & 3.47 & 5.26 & 7.69 & 7.99 & 1.10 & 1.72 & 2.70 & 2.07 \\
\hline SAS & 0.07 & 0.13 & 0.19 & 0.18 & -0.94 & -1.11 & -1.28 & -1.11 & -0.45 & -0.76 & -1.11 & -0.82 & -0.25 & -0.39 & -0.41 & -0.15 \\
\hline SEA & 0.62 & 0.75 & 1.01 & 0.99 & 0.84 & -1.53 & -3.92 & -1.54 & 0.65 & -0.75 & -1.95 & -1.27 & 0.86 & 0.36 & -0.20 & 0.30 \\
\hline $\mathrm{CHI}$ & 0.18 & 0.41 & 0.99 & 0.74 & 0.48 & 0.53 & 0.61 & 0.50 & 0.18 & -0.19 & -0.18 & 1.55 & -0.47 & -1.85 & -3.77 & -1.74 \\
\hline NAF & 1.32 & 0.25 & -1.81 & 0.76 & -0.35 & -1.80 & -3.34 & -1.81 & -0.20 & -2.06 & -4.15 & -2.06 & 0.25 & 0.01 & -0.24 & 0.20 \\
\hline SSA & -1.00 & -1.02 & -1.08 & -1.10 & -2.35 & -4.12 & -6.05 & -4.19 & 0.74 & 0.22 & -0.36 & -0.27 & 1.74 & 2.35 & 3.42 & 3.76 \\
\hline ROW & -0.14 & -0.14 & -0.14 & -0.16 & -2.78 & -2.90 & -3.07 & -2.92 & 0.19 & -0.63 & -1.49 & -0.83 & 0.96 & 0.92 & 0.90 & 0.90 \\
\hline
\end{tabular}


scenarios 2 and 3 affect production positively.

The effect of liberalization on the production of vegetables and fruits in developed countries is predominantly negative. Exceptions are the USA and Canada. In Canada, production increases less with more liberalization. In the developing world, countries in Central and South America and in Sub-Saharan Africa would increasingly expand their production. The opposite is true for China and countries in South Asia. For other regions, scenario 1 affects production positively while a more ambitious liberalization has a negative affect.

The above discussion indicates that effects of liberalization on the regions are not uniform, and not linear or even monotone in the degree of liberalization.

Comparing scenarios 2 (50 per cent tariff reduction everywhere) and 4 ( 75 per cent in developed regions, 50 per cent in developing ones) shows a negative effect on production in developing regions, either due to smaller increase or a greater decrease in production. Positively affected are rice production in China and South East Asia, wheat production in Central and South America, the production of cereals and other crops in South America and China, and the production of vegetables and fruits in the Middle East, South America, and Africa. Comparing scenarios 3 (75 per cent tariff reduction everywhere) and 4, we find a mixed picture for the developing regions and a more negative one for the developed ones. Changes in production are generally more positive or less negative for vegetables and fruits and other cereals. For wheat and rice, the picture is mixed. Regions such as the Middle East, South America and China experience a lower increase in wheat production while other regions experience a lower decrease.

Figure 1 shows the effect of the four trade liberalization scenarios on water use in developed (top panel) and developing (bottom panel) countries.

Trade liberalization would imply an increase in water use in Canada, Australia and New Zealand, and Eastern Europe; and a reduction in Western Europe, Japan and South Korea, and the former Soviet Union. The USA would see a decrease in water use for a partial liberalization, but an increase for a more complete liberalization; China would see an increase first, and then a decrease. Among the developing regions, the Middle East, South America, South-East Asia and SubSaharan Africa would see an increase in water use; and Central America, South Asia, and North Africa a decrease. In all cases, changes in water use due to trade liberalization are less than 10 per cent.

Figure 2 shows that trade liberalization (implemented by scenarios 1 to 3 ) enhances the current pattern in virtual water trade, that is, regions that are currently 
Figure 1. Changes in Water Use Relative to the Baseline in the 4 Alternative Trade Liberalization Scenarios, for Developed (top panel) and Developing (bottom panel) Economies.

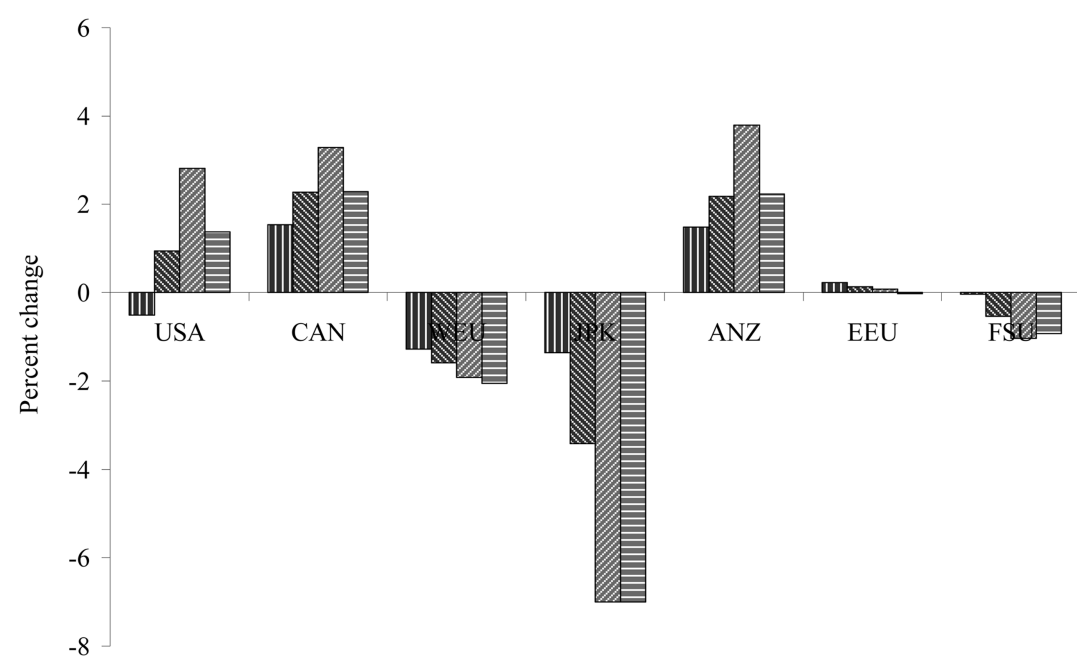

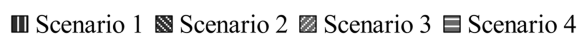

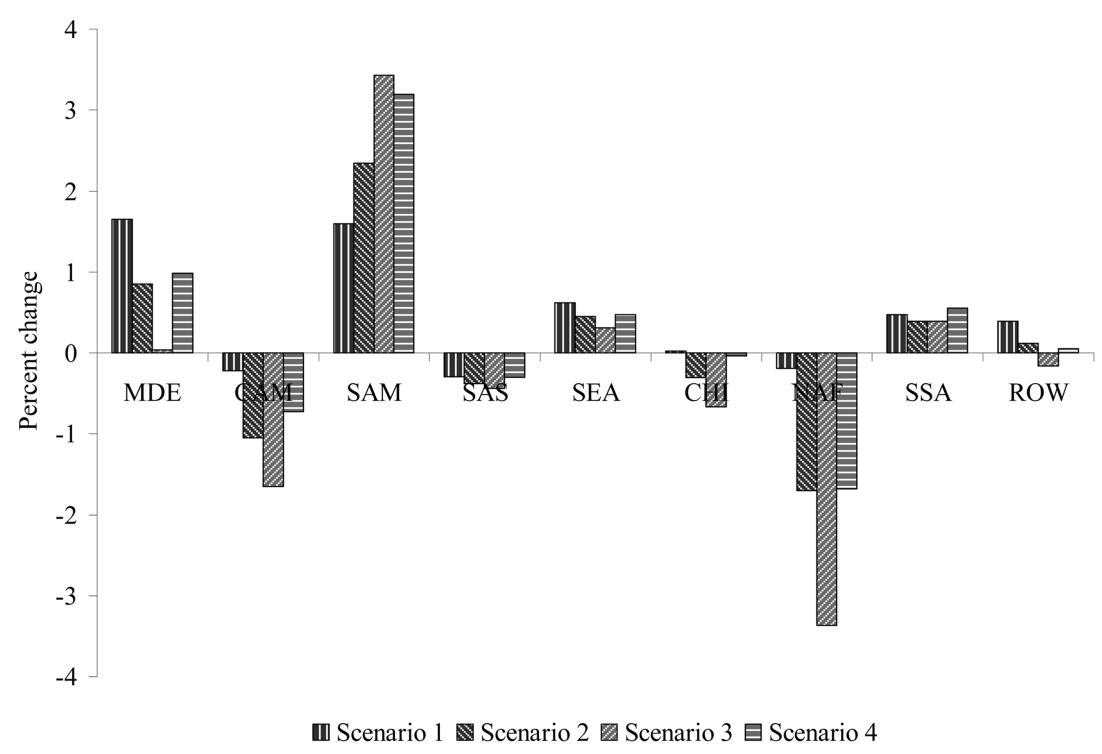

substantial exporters of virtual water (negative virtual water import balance in Figure 2), use even more water; while regions that presently import virtual water, use even less domestic water. The simple quadratic curves fitted in Figure 2 explain more than 50 per cent of the variance. Tariffs restrain, but do not reverse the comparative advantages of regional agricultural production. Results from 
Figure 2. The change in water demand relative to the baseline as a function of the water balance before trade liberalization. The current water balance is defined as virtual water import minus virtual water export over total water use; -1 means that all water is used for exports; +1 means that water imports double the water available in the region itself. The results for each region are vertically aligned; the initial situation is where that vertical line crosses the $\mathrm{x}$-axis.

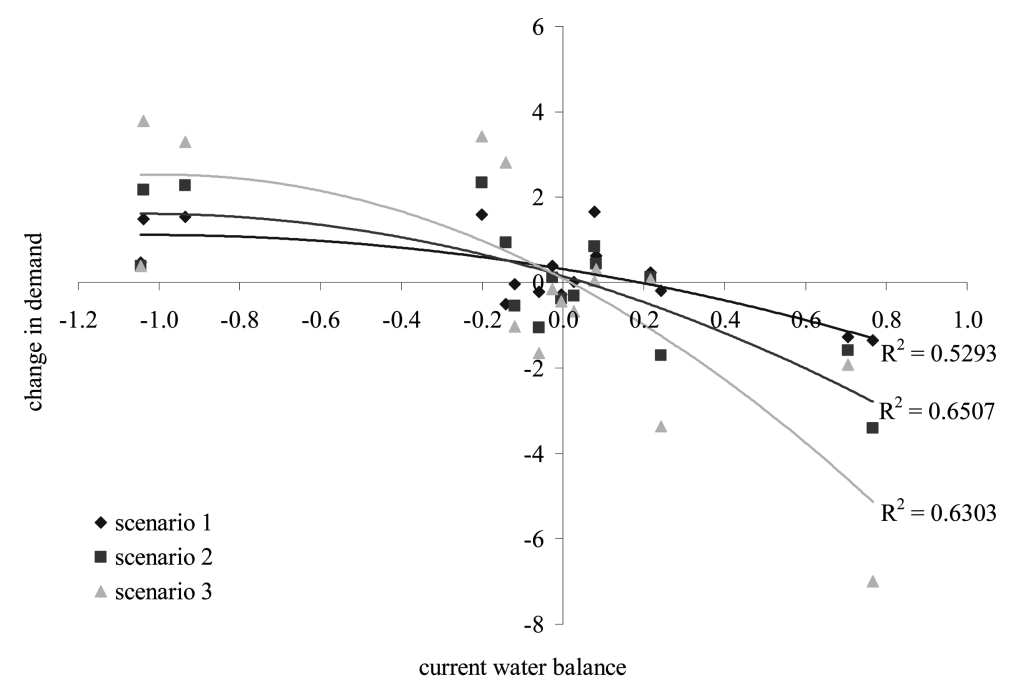

Scenario 4 are omitted from Figure 2, as it is not directly comparable to the other scenarios.

Figures 3 and 4 (again based on scenarios 1 to 3 ) demonstrate that there is no relationship between either the absolute water scarcity (in cubic metre per person per year; Figure 3) or the implied value of water (in cubic metre per value added per year; Figure 4) on the one hand, and the change in water demand on the other hand. This is as expected, because water is not a market good. Neither scarcity nor price of water is taken into consideration in decisions on agricultural production.

Trade liberalization would reduce water use in South Asia and North Africa, two regions that unsustainably use fossil ground water (cf. Berrittella et al., 2007). China and the USA are also depleting their fossil water resources, but water use goes up in some trade liberalization scenarios, and down in others. Water use decreases due to trade liberalization in water scare Japan and South Korea. The same is true for the water scarce regions in North Africa. In the Middle East, water demand increases with modest tariff reductions but the increase is smaller the more ambitious the reduction. Overall, trade liberalization reduces water stress for the world as a whole and for most regions. This is by happenstance rather than design, 
Figure 3. The change in water demand relative to the baseline as a function of the water intensity before trade liberalization. The results for each region are vertically aligned; the initial situation is where that vertical line crosses the $\mathrm{x}$-axis.

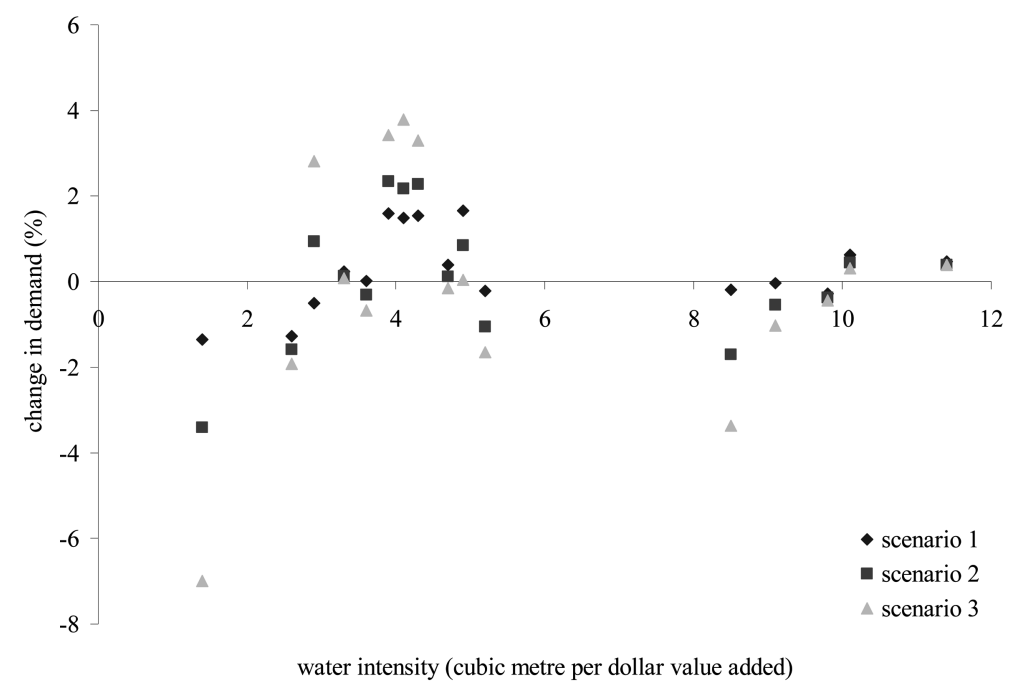

Figure 4. The change in water demand relative to the baseline as a function of the renewable water resource per capita. The results for each region are vertically aligned; the initial situation is where that vertical line crosses the $\mathrm{x}$-axis.

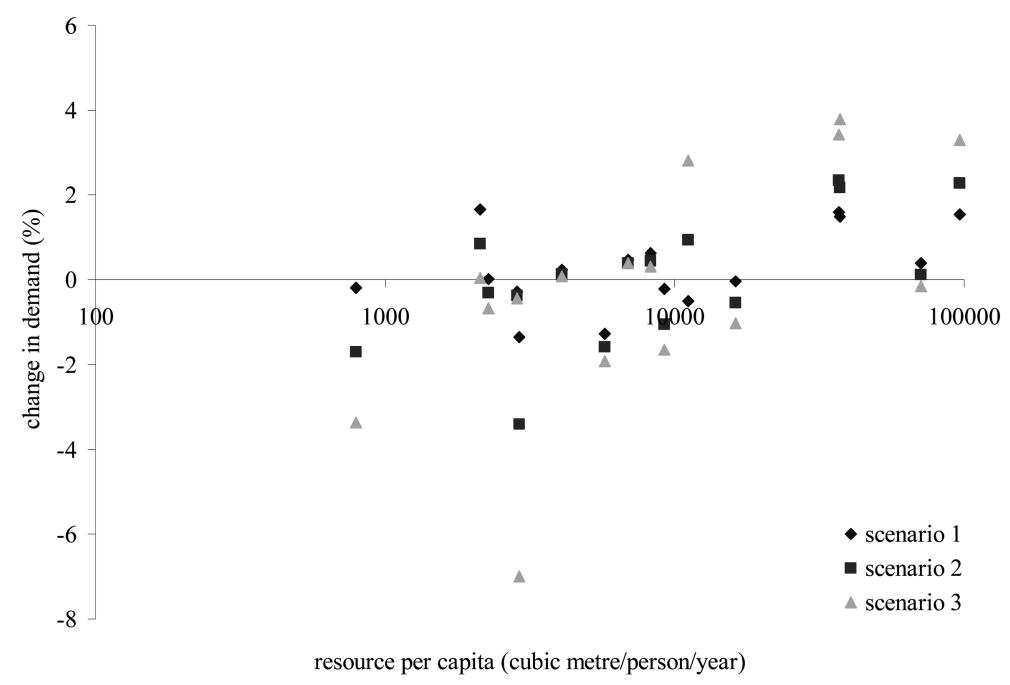

since sustainable water policy scenarios for water short regions do not accompany our trade liberalization scenarios. 


\section{Discussion and Conclusion}

In this paper, we estimate the effect of reductions in subsidies and import tariffs for agricultural production on water consumption, using a global static computable general equilibrium model with 16 regions and 17 sectors. We find that trade liberalization has a small effect (less than 10 per cent) on water use. Water use for some crops and some regions goes up, and it goes down for other crops and regions. This can lead to mixed pattern in total water use for some regions. For example, a modest liberalization decreases (increases) water use in the USA (China), but the sign switches for more substantial trade liberalization. Although the changes in water use are unrelated to either physical notions of water scarcity (here, water resource per capita) or economic notions of water scarcity (here, value added per water use), it turns out that trade liberalization reduces water use in places where it is scarce, and increases water use in places where it is more abundant.

A number of caveats apply to the above results. The model is static. A dynamic model may find larger effects of trade liberalization with further specialization through capital stock adjustments. Water is treated as a technology parameter, rather than an input factor. This implies that substitution away from water is limited, although it should be noted that water scarcity does not play a prominent role in this analysis. Water is treated as a homogenous good within regions, which increases substitutability. Water is traded implicitly among regions through trade in agricultural products. The limited disaggregation of crops and regions may hide larger shifts in agricultural production and water use due to trade liberalization. The importance of these factors will need to be tested with a future version of the current model and with other models. Trade liberalization is the only policy considered. Future applications should consider liberalization along with the creation of water markets or the introduction of water charges.

These caveats notwithstanding, the current analysis shows that agricultural trade liberalization would have a small and largely beneficial effect on the use of water resources.

\section{Acknowledgements}

The authors are grateful to two anonymous referees and Tom Hertel for constructive comments on an earlier draft, to Roberto Roson for excellent comment on model design, and to the Michael Otto Foundation for Environmental Protection 
for financial support.

Received 30 June 2007, Revised 7 March 2008, Accepted 8 April 2008

\section{References}

Ahmad, M. (2000). Water Pricing and Markets in the Near East: Policy Issues and Options, Water Policy 2, 229-242.

Allan, J.A. (1992). Fortunately there are substitutes for water otherwise our hydropolitical futures would be impossible. In: Proceedings of the Conference on Priorities for Water Resources Allocation and Management: Natural Resources and Engineering Advisers Conference, Southampton, July 1992, pp. 13-26.

Allan, J.A. (1993). Overall Perspectives on Countries and Regions. In: Rogers, P. and Lydon, P. (Eds.) Water in the Arab World: Perspectives and Prognoses, Cambridge, Massachusetts, pp. 65-100.

Anderson, K., Martin, W. and van der Mensbrugghe, D. (2006) Would Multilateral Trade Reform Benefit Sub-Saharan Africans? Journal of African Economies 15, 626-670.

Berrittella, M., Hoekstra, A., Rehdanz, K., Roson, R. and Tol, R.S.J. (2007) The Economic Impact of Restricted Water Supply: A Computable General Equilibrium Analysis, Water Research 42, 1799-1813.

Berrittella, M., Rehdanz, K., Roson, R. and Tol, R.S.J. (2008) The Economic Impact of Water Pricing: A Computable General Equilibrium Analysis, Water Policy 10, 259-271.

Berrittella, M., Rehdanz, K. and Tol, R.S.J. (2006) The Economic Impact of the SouthNorth Water Transfer Project in China: A Computable General Equilibrium Analysis, Research unit Sustainability and Global Change FNU-117, Hamburg University and Centre for Marine and Atmospheric Science, Hamburg.

Bureau, J.-C., Jean, S. and Matthews, A. (2006) The Consequences of Agricultural Trade liberalization for Developing Countries: Distinguishing between Genuine Benefits and False Hopes. World Trade Review 5, 225-249.

Chapagain, A.K. and Hoekstra, A.Y. (2004). Water Footprints of Nations, Value of Water Research Report Series No. 16, UNESCO-IHE Delft, The Netherlands.

Chichilnisky, G. (1994) North-South Trade and the Global Environment. American Economic Review 84(4), 851-874.

Decaluwé, B., Patry, A. and Savard, L. (1999). When Water is no Longer Heaven Sent: Comparative Pricing Analysis in a AGE Model, Working Paper 9908, CRÉFA 99-05, Départment d'économique, Université Laval.

Diao, X. and Roe, T. (2003). Can a Water Market Avert the "Double-whammy" of Trade Reform and Lead to a "Win-win" Outcome? Journal of Environmental Economics and Management 45, 708-723.

Dimaranan, B. V., and R. A. McDougall (2002). Global Trade, Assistance, and Production: The GTAP 5 Data Base. Center for Global Trade Analysis, Purdue University. Available on-line at http://www.gtap.agecon.purdue.edu/databases/v5/v5_doco.asp. 
Feng, S., Li, L.X., Duan, Z.G. and Zhang, J.L. (2007) Assessing the Impacts of South-toNorth Water Transfer Project with Decision Support Systems. Decision Support Systems 42 (4), 1989-2003.

FAO (2003) AQUASTAT database, http://www.fao.org/ag/aquastat/.

FAO (2004) FAOSTAT database, http://faostat.fao.org/.

Fraiture, C. de, Cai, X., Amarasinghe, U., Rosegrant, M. \& Molden, D. (2004). Does International Cereal Trade Save Water? The Impact of Virtual Water Trade on Global Water Use. Comprehensive Assessment Research Report 4, Colombo, Sri Lanka.

Francois, J., van Meijl, H. and van Tongeren, F. (2005) Trade Liberalization in the Doha Development Round. Economic Policy (April), 349-391.

George, C. and Kirkpatrick, C. (2004) Trade and Development: Assessing the Impact of Trade Liberalization on Sustainable Development. Journal of World Trade 38, 441-469.

Gómez, C.M., Tirado, D. and Rey-Maquieira, J. (2004). Water Exchange versus Water Work: Insights from a Computable General Equilibrium Model for the Balearic Islands, Water Resources Research 42, W10502 10.1029/2004WR003235.

Goodman, D.J. (2000). More Reservoir or Transfer? A Computable General Equilibrium Analysis of Projected Water Shortages in the Arkansas River Basin, Journal of Agricultural and Resource Economics 25(2), 698-713.

Hertel, T.W. (1997). Global Trade Analysis: Modeling and applications, Cambridge University Press, Cambridge.

ILO (2006a). Total and Economically Active Population, Estimates and Projections, 1980-2020, International Labour Organization, Geneva.

ILO (2006b). LABORSTA, Labour Force Survey, International Labour Organization, Geneva.

Johannson, R.C., Tsur, Y., Roe, T.L., Doukkali, R. and Dinar, A. (2002). Pricing Irrigation Water: A Review of Theory and Practice, Water Policy 4, 173-199.

Kirkpatrick, C. and D. Parker (2005) Domestic Regulation and the WTO: The Case of Water Services in Developing Countries, World Economy 28, 1491-1508.

Lee, H., Oliveira-Martins, J. and van der Mensbrugghe, D. (1994) The OECD GREEN Model: An Updated Overview, Working Paper No. 97, OECD, Paris.

Letsoalo, A., J. Blignaut, T. de Wet, M. de Wit, S. Hess, R.S.J. Tol and J. van Heerden (2007) Triple Dividends of Water Consumption Charges in South Africa. Water Resources Research 43, W05412.

Rosegrant, M.W., Cai, X. and Cline, S.A. (2002). World Water and Food to 2025: Dealing with Scarcity. International Food Policy Research Institute, Washington.

Seung, C.K., Harris, T.R., Eglin, J.E. and Netusil, N.R. (2000). Impacts of Water Reallocation: A Combined Computable General Equilibrium and Recreation Demand Model Approach, The Annals of Regional Science 34, 473-487.

Strzepek, K.M., G.W. Yohe, R.S.J. Tol and M. Rosegrant (2006), The Value of the High Aswan Dam to the Egyptian Economy, Research unit Sustainability and Global Change FNU111, Hamburg University and Centre for Marine and Atmospheric Science, Hamburg.

United Nations (2005). World Population Prospects: The 2004 Revision. Population Division of the Department of Economic and Social Affairs of the United Nations Secretariat, 2005. United Nations, New York. 
Watson, C. (2004) Trade and Water - The Role of WTO and GATS: Opening the Water

Sector to new Service Providers, WaterAid.

WDI (2006). World Development Indicators 2006, World Bank, Washington, D.C.

\section{Annex I}

Table A1. Aggregations in GTAP-W

\begin{tabular}{ll}
\hline \multicolumn{1}{c}{ A. Regional Aggregation } & \multicolumn{1}{c}{ B. Sectoral Aggregation } \\
\hline Developed Regions & Agriculture \\
1. USA - United States & 1. Rice - Rice \\
2. CAN - Canada & 2. Wheat - Wheat \\
3. WEU - Western Europe & 3. CerCrops - Other cereals and crops \\
4. JPK - Japan and Korea & 4. VegFruits - Vegetable, Fruits \\
5. ANZ - Australia and New Zealand & 5. Animals - Animals \\
6. EEU - Eastern Europe & 6. Forestry - Forestry \\
7. FSU - Former Soviet Union & 7. Fishing - Fishing \\
& Non-agricultural sectors \\
Developing Regions & 8. Coal - Coal Mining \\
8. MDE - Middle East & 9. Oil - Oil \\
9. CAM - Central America & 10. Gas - Natural Gas Extraction \\
10. SAM - South America & 11. Oil_Pcts - Refined Oil Products \\
11. SAS - South Asia & 12. Electricity - Electricity \\
12. SEA - Southeast Asia & 13. Water - Water collection, purification and \\
13. CHI - China & distribution services \\
14. NAF - North Africa & 14. En_Int_ind - Energy Intensive Industries \\
15. SSA - Sub-Saharan Africa & 15. Oth_ind - Other industry and services \\
16. ROW - Rest of the world & 16. MServ - Market Services \\
& 17. NMServ - Non-Market Services \\
\hline
\end{tabular}

Table A2. Water Price Parameters

\begin{tabular}{lcc}
\hline & Agricultural sectors & Water distribution services \\
\hline 1 USA & -0.14 & -0.72 \\
2 CAN & -0.08 & -0.53 \\
3 WEU & -0.04 & -0.45 \\
4 JPK & -0.06 & -0.45 \\
5 ANZ & -0.11 & -0.67 \\
6 EEU & -0.06 & -0.44 \\
7 FSU & -0.09 & -0.67 \\
8 MDE & -0.11 & -0.77 \\
9 CAM & -0.08 & -0.53 \\
10 SAM & -0.12 & -0.80 \\
11 SAS & -0.11 & -0.75 \\
12 SEA & -0.12 & -0.80 \\
13 CHI & -0.16 & -0.80 \\
14 NAF & -0.07 & -0.60 \\
15 SSA & -0.15 & -0.80 \\
16 ROW & -0.20 & -0.85 \\
\hline
\end{tabular}

Source: Our elaboration from Rosegrant et al. (2002). 
Figure A1. Nested Tree Structure for Industrial Production Process

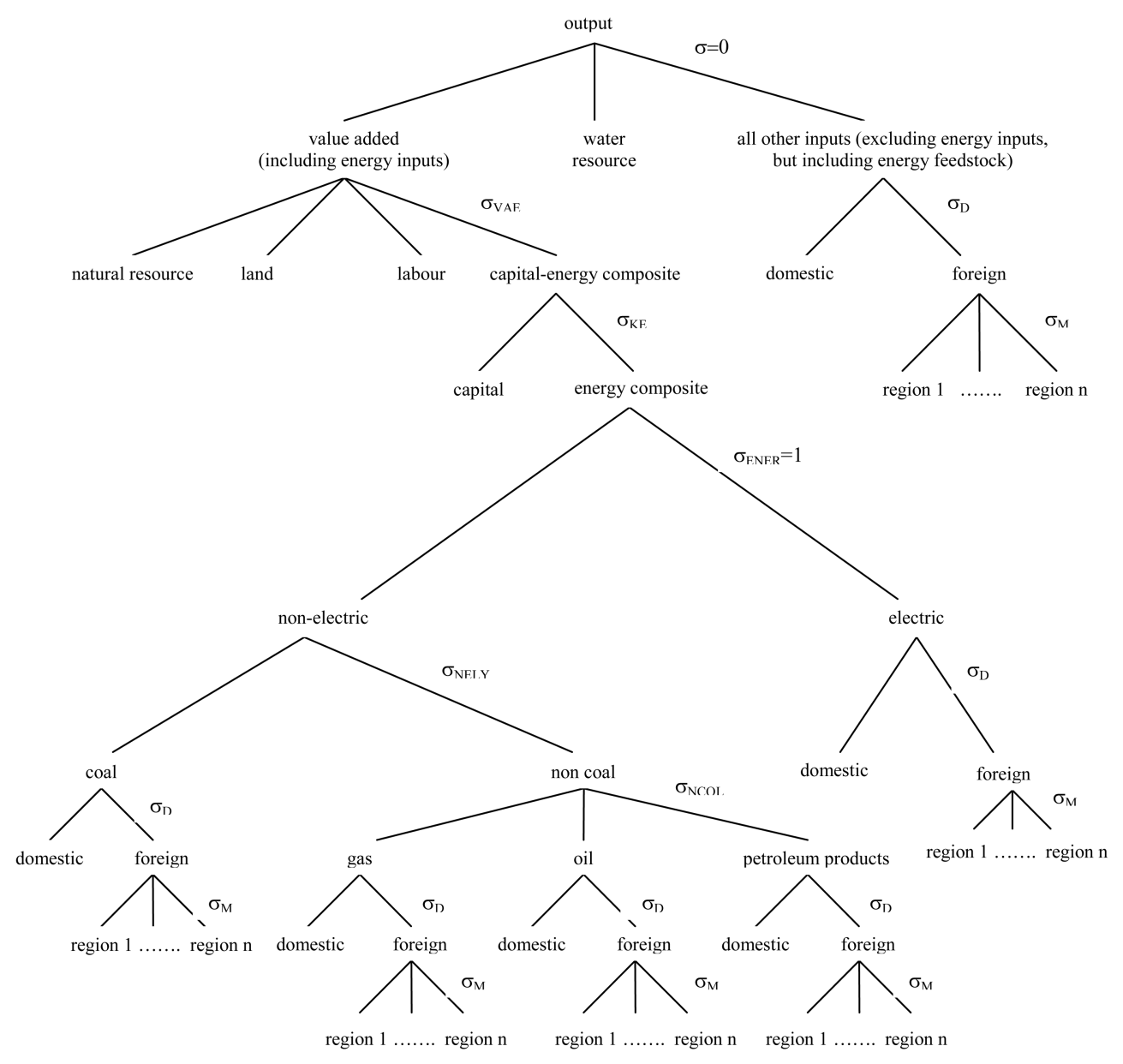

\section{Annex II}

The economic rent associated with water resources (WRR) has been modelled as an output tax (subsidy); the formulation follows the GTAP standard. If there is no water scarcity, we have $W R R=0$. If water is scarce, the economic rents associated with water resources drive a wedge between the market price $(P M)$ and the agents' price $(P S)$. This wedge is called the power of the water rent and it is calculated as follows:

$$
W R P(i, r)=\frac{\operatorname{VOM}(i, r)-V W R(i, r)}{\operatorname{VOM}(i, r)}
$$


where, for any commodity $i$ in region $r$, we have that $\operatorname{WRP}(i, r)$ is the power of the water rent, $\operatorname{VOM}(i, r)$ is the value of output evaluated at market price and $\operatorname{VWR}(i, r)$ is the value of the water rent, that is the quantity of water resources $\left(\mathrm{km}^{3}\right)$ multiplied by the water rent per $\mathrm{km}^{3}$.

In the initial equilibrium, the water rent $\left(W R R_{0}\right)$ is equal to zero, and the agents' price $\left(P S_{0}\right)$ and the market price $\left(P M_{0}\right)$ coincide. Thus, the power of the rent is equal to 1 . If the water rent increases (decreases), the power of the water rent becomes smaller (higher) than 1 . This affects the supply price.

The relation between supply prices, market prices, output taxes and the economic rent associated with water resources is as follows:

$$
p s(i, r)=p m(i, r)+t o(i, r)+w r p(i, r)
$$

where, for any commodity $i$ in region $r$, we have that $p m(i, r)$ is the percentage change in the market price $P M, p s(i, r)$ is the percentage change in the supply price, $t o(i, r)$ is the percentage change in the power of the output tax, and $w r p(i, r)$ is the percentage change in the power of the economic rent associated with water resources. If the water rent increases, the power of the water rent falls, and the wedge between the supply price and the market price grows.

The water demand by industry $i$ in region $r$ is sensitive to the change of the supply price due to the change of the water rent as follows:

$$
q w t(i, r)=q o(i, r)-\varepsilon(i, r) w r p(i, r)
$$

where for any commodity $i$ in region $r$, we have that $q w t(i, r)$ is the percentage change in the water demand, qo $(i, r)$ is the percentage change of the output and $\varepsilon(i, r)$ is the water price sensitivity.

\section{Annex III Scenario for 2010}

\section{Population}

Data on population projection was taken from the UN World Population Prospects (United Nations, 2005). This dataset covers demographic projections until 2050 for all countries. For most OECD countries changes in population are positive but much below world average. Negative changes are projected for Eastern Europe as well as the former Soviet Union. Highest positive changes are projected for Sub-Saharan Africa, South Asia and the Middle East. 


\section{Labour Force}

Information on changes in labour force was taken from ILO (International Labor Organization) estimates (ILO, 2006a) and projections of the economically active population ( $5^{\text {th }}$ edition). Annual data is available for the period $1980-2020$ on country level. Again, most OECD countries as well as for China changes are below average, negative changes are projected for Japan as well as for Eastern Europe. Positive changes are particularly pronounced for the Middle East, North Africa, South America and South Asia.

\section{Capital Stock}

To derive information on the capital stock in 2010, data from the World Development Indicators (WDI, 2006) on gross fixed capital formation was taken until the most recent year available which is 2004 . This information was used to increase the capital stock from 1997 (provided by the GTAP database) to 2004. For depreciation, a rate of 4 per cent was assumed. In the next step the information on the average change in capital stock per country between 1997 and 2004 was used to calculate the capital stock in 2010. Data was interpolated for countries where observations were missing for some years between 1997 and 2004. For a number of countries data was unavailable. For those, regional averages are based on values for countries within a region where data was available.

A marked increase in capital stock is projected for China. This is due to the substantial annual increases in gross investment of about 10 per cent in the period 1997 to 2004. Regions with increases below world average are Middle East and Africa.

\section{Labour Productivity}

A single factor productivity measure such as labour productivity is measured by calculating the ratio of a volume measure of output to a volume measure of input use. Mainly gross output or value added are used as output measures. We used value added per employed person per sector.

Data on employment by sector was taken from the ILO Labour Force Survey (ILO, 2006b). They provide annual information until 2005 per country based on the ISIC Rev. 3 classification, sometimes only on the older and less detailed ISIC Rev.2 classification. As our sectoral aggregation is different from the ISIC classification we collected data for two sectors only, agricultural sector and all other sectors together. In our aggregation of the energy intensive sectors, for example, sectors are included that refer to different ISIC classifications (omn/mining of uranium etc. is ISIC3 C 
(mining and quarrying) while crp/manufacture of basic chemicals etc. is ISIC3 D (manufacturing)).

Data on value added by sector and country was available from the World Development Indicators (WDI, 2006) until 2004. We calculated the value added for two sectors, agriculture and industry plus services. In a next step the annual labour productivity growth per country for the two sectors was calculated until 2004.

The information on the average growth per country between 1997 and 2004 was used to calculate the change in productivity until 2010. Data was interpolated for countries where observations were missing for some years between 1997 and 2004. For a number of countries data was unavailable. For those, regional averages are based on values for countries within a region where data was available.

For the agricultural sector, changes in labour productivity are above average for all OECD countries and particularly pronounced for the USA. However, other regions like Eastern Europe, the former Soviet Union and China show high increases as well. With respect to all other sectors, changes are less pronounced for most regions, except for China, the former Soviet Union and South Asia. Japan is the only OECD region with less than world average growth rates.

\section{Land Productivity}

To calculate the growth in land productivity data on agricultural production and area harvested was taken from FAO's most recent agricultural statistics. Country level data on individual crop types is available until 2004. This information was aggregated to our four different crop sectors rice, wheat, cereals and other crops, fruits and vegetables. As information on area used for animal husbandry was not available the average growth in land productivity calculated for the four crop sectors together was used as an approximation.

To calculate the change in agricultural land productivity until 2010, the average growth rate between 1997 and 2004 was used.

For wheat and other crops and cereals increases in land productivity are significant for Eastern Europe and the former Soviet Union. For vegetables and fruits Central America and South and South East Asia show pronounced increases. 
Table A3. Exogenous Changes for Baseline Scenario 2010.

\begin{tabular}{|c|c|c|c|c|c|c|c|c|c|c|}
\hline & \multirow{2}{*}{$\begin{array}{l}\text { Popula- } \\
\text { tion }\end{array}$} & \multirow{2}{*}{$\begin{array}{l}\text { Capital } \\
\text { Stocks }^{1}\end{array}$} & \multirow{2}{*}{$\begin{array}{l}\text { Labor } \\
\text { Stocks }^{1}\end{array}$} & \multicolumn{2}{|c|}{$\begin{array}{c}\text { Labour } \\
\text { productivity }^{2}\end{array}$} & \multicolumn{5}{|c|}{ Land productivity $^{2}$} \\
\hline & & & & Agriculture & Other & Rice & Wheat & Cereals & Veg\&Fruits & Animals \\
\hline USA & 13.38 & 79.72 & 13.21 & 157.37 & 32.24 & 23.75 & 42.12 & 14.31 & -5.17 & 6.77 \\
\hline CAN & 12.80 & 62.59 & 20.98 & 51.15 & 41.15 & 0.00 & 29.18 & 17.80 & -1.13 & 5.95 \\
\hline WEU & 3.70 & 54.37 & 7.58 & 79.43 & 26.74 & 17.54 & 16.48 & 16.68 & 21.76 & 18.49 \\
\hline JPK & 2.96 & 53.10 & -0.42 & 48.56 & 0.91 & 1.97 & 65.59 & 7.33 & 10.14 & 4.98 \\
\hline ANZ & 14.73 & 59.48 & 20.38 & 51.60 & 36.19 & 77.73 & 97.95 & -6.81 & -5.65 & -5.52 \\
\hline EEU & -2.72 & 40.28 & -4.39 & 107.83 & 36.22 & 123.30 & 116.32 & 89.18 & -18.95 & 17.50 \\
\hline FSU & -2.98 & -2.98 & 3.75 & 114.33 & 74.51 & 79.17 & 96.60 & 89.63 & 12.28 & 46.81 \\
\hline MDE & 28.16 & 7.25 & 46.85 & 15.97 & -7.43 & 61.49 & 37.82 & 12.12 & 20.39 & 25.10 \\
\hline CAM & 19.99 & 70.68 & 26.89 & 34.89 & 4.70 & 16.33 & 18.32 & 38.68 & 50.35 & 49.34 \\
\hline SAM & 20.00 & 24.58 & 31.92 & 51.79 & -15.03 & 46.89 & 31.56 & 21.31 & -26.81 & -14.11 \\
\hline SAS & 23.62 & 96.93 & 28.51 & 9.02 & 48.71 & 23.57 & 20.38 & 16.72 & 47.60 & 33.53 \\
\hline SEA & 18.89 & 46.66 & 29.52 & 25.43 & -2.92 & 20.67 & -5.89 & 27.15 & 33.23 & 28.79 \\
\hline $\mathrm{CHI}$ & 9.06 & 226.75 & 11.70 & 51.68 & 140.08 & 2.96 & 26.90 & 13.28 & 30.46 & 37.84 \\
\hline NAF & 24.15 & 32.59 & 42.07 & 28.02 & 4.29 & 33.04 & 31.88 & 44.72 & 28.57 & 38.90 \\
\hline SSA & 34.67 & 14.47 & 33.60 & 29.65 & -4.86 & -25.14 & 5.14 & -2.90 & 5.43 & 7.86 \\
\hline ROW & 21.53 & -23.08 & 27.25 & -6.13 & 35.25 & 47.98 & 201.09 & 76.53 & 7.29 & 36.48 \\
\hline
\end{tabular}

"This is an exogenous change to "qo" in the GTAP model.

${ }^{2}$ This is an exogenous change to "afeall" in the GTAP model. 